\title{
Universiteit
}

Leiden

The Netherlands

\section{Reduplication in the Vedic verb: Indo-European inheritance, analogy and iconicity}

Kulikov, L.I.; Hurch B., Mattes V.

\section{Citation}

Kulikov, L. I. (2005). Reduplication in the Vedic verb: Indo-European inheritance, analogy and iconicity. In M. V. Hurch B. (Ed.), Studies on reduplication (pp. 431-454). Berlin: Mouton d Gruyter. Retrieved from https://hdl.handle.net/1887/14532

Version: $\quad$ Not Applicable (or Unknown)

License: $\quad$ Leiden University Non-exclusive license

Downloaded from: $\quad$ https://hdl.handle.net/1887/14532

Note: To cite this publication please use the final published version (if applicable). 


\title{
Bernhard Hurch (Editor)
}

\section{Studies on Reduplication}

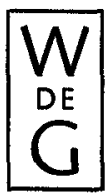

\author{
Mouton \\ de Gruyter
}


Mouton de Gruyter (formerly Mouton, The Hague)

is a Division of Walter de Gruyter GmbH \& Co. KG, Berlin.

(2) Printed on acid-free paper which falls within the guidelines of the ANSI to ensure permanence and durability.

Library of Congress Cataloging-in-Publication Data

Studies on reduplication / edited by Bernhard Hurch.

p. cm. - (Empirical approaches to language typology ; 28)

Includes bibliographical references and index.

ISBN 3-11-018119-3 (cloth : alk, paper)

1. Grammar, Comparative and general - Reduplication. I. Hurch, Bernhard. II. Series.

P245.S855 2005

$415-\mathrm{dc} 22$

\section{ISBN 3110181193}

\section{Bibliographic information published by Die Deutsche Bibliothek}

Die Deutsche Bibliothek lists this publication in the Deutsche Nationalbibliografie; detailed bibliographic data is available in the Internet at $<\underline{\text { http: } / / \text { dnb.ddb.de }}>$.

(c) Copyright 2005 by Walter de Gruyter GmbH \& Co. KG, D-10785 Berlin.

All rights reserved, including those of translation into foreign languages. No part of this book may be reproduced or transmitted in any form or by any means, electronic or mechanical, including photocopy, recording or any information storage and retrieval system, without permission in writing from the publisher.

Printed in Germany. 


\title{
Reduplication in the Vedic verb: Indo-European inheritance, analogy and iconicity ${ }^{1}$
}

\author{
Leonid Kulikov
}

\section{Preliminary remarks}

Vedic, the language of the oldest well-known Indian religious tradition and the oldest attested Indo-Aryan language (the earliest texts are dated to the second half of the second millennium B.C.), exhibits an extremely rich and quite intricate system of reduplicated verbal formations. Old Indo-Aryan seems to preserve the original Proto-Indo-European system of verbal reduplication better than any other ancient Indo-European language, developing further a few marginal and rare types.

There are at least five verbal formations which use reduplication:

- perfect (cf. vrdh 'grow' - vavárdha 'has grown'),

- reduplicated present (class III in traditional notation, cf.: dā 'give' dádāti 'gives', gā 'go'-jígàti 'goes'),

- reduplicated (causative) aorist (cf. jan 'be born, generate' - ájījanat 'generated'),

- desiderative (cf. $d \bar{a}$ 'give' - dídāsati '(s/he) wishes to give') and

- two types of intensive (denoted as 'intensive I' and 'intensive II' in Lubotsky 1997a) - without the suffix - yá- and with this suffix (cf. yam 'hold' - yamyamiti 'holds (repeatedly)'; mrj 'wipe, cleanse' - marmrjyáte 'wipes, cleanses (repeatedly)').

Some of these formations are inherited from Proto-Indo-European, as the evidence from other Indo-European branches clearly shows, whereas some others are likely to represent Indo-Iranian or Indo-Aryan innovations.

Four of the five formations have been the subject of monographic study: perfect in Kümmel 2000, reduplicated aorist in Bendahman 1993, intensive in Schaefer 1994, desiderative in the unpublished thesis Heenen 2002 (and see also the important paper Insler 1968). A monographic description of the reduplicated present (which is perhaps the most intriguing member of the 
group) remains a desideratum, however, ${ }^{2}$ and no systematic treatment of the Vedic verbal reduplication types in general has appeared so far either. ${ }^{3}$

It is of course impossible to give an exhaustive description of the Vedic verbal reduplication within a short article. Rather, I will present a survey of the reduplication types, attested, above all, in the oldest Vedic texts, Rgveda (RV) and Atharvaveda (AV), summarizing the main relevant facts and focusing on the most interesting formal and semantic oppositions.

\section{Formal parameters of reduplication}

In order to systematize the types attested in the Vedic verb, we first have to describe and catalogue the relevant formal parameters of reduplication (a good survey can be found, for instance, in Macdonell 1916: 123).

\subsection{Reduplication consonant $\left(C_{R}\right)$}

The rules for the reduplication of the root consonant are almost the same for the main reduplication types. They can be briefly summarized as follows:

- aspirates lose their aspiration (Grassman's law) and velars are (mostly) palatalized to $c$ or $j(k(h) \rightarrow c ; g(h), h \rightarrow j)$, cf. dhä 'put' - dádhāti 'puts', gam 'go'-jagam-, khan 'dig' - cakhan-, etc.;'

- only the first (anlaut) consonant of the root is reduplicated (cf. prā 'fill' papráu 'has filled'), except for roots beginning with a $s T$-cluster $(T=$ an obstruent stop), where the stop is reduplicated (cf. sth $\bar{a}$ 'stand' - tișțhati 'stands').

\subsection{Reduplication vowel}

\subsubsection{Root-dependent vs. root-independent reduplication vowel}

There are two main techniques which determine the quality of the reduplication vowel: it either depends on the root vocalism ${ }^{5}$ or is root-independent.

In the case of the root-dependent reduplication vowel, the reduplication syllable copies the root vocalism 
- either in its full grade ('intensive reduplication'), cf. yam 'hold' ya myamīti, mrj / marj 'wipe, cleanse' - marmrj-;

- or in the weak (zero) grade, cf. cyu 'move, shake' - pf. cucyuvé 'has moved, has shaken', dis' 'point (out)' - pres. didis'-, dideś.

Some verbal formations exhibit a root-independent reduplication vowel. In fact, no reduplicated formation applies this technique across the board, since the $\breve{u}$ and $\tilde{l}$ roots always copy the root vocalism in the reduplication syllable, which can be considered as an instance of vowel harmony, or vowel assimilation (see e.g. Meillet 1903: 215). ${ }^{6}$ The rules determining the choice of the reduplication vowel for the 'non-harmonizing' roots $(V \neq \breve{u}$, i) can be briefly summarized as follows (for details, see Section 3):

(i) for perfect: $a$ or $\bar{a}$;

(ii) for reduplicated aorist and desiderative: $i$ or $\bar{i}$;

(iii) for reduplicated present: same pattern as under (ii) (aorist and desiderative), except for some $a$-roots, which reduplicate with $a$ instead of $i$ (cf. $d \bar{a}$ 'give' - dádāti 'gives').

\subsubsection{Lengthening of the reduplication vowel}

The reduplication vowel becomes long in aorists (cf. budh 'wake' $a b a b u d h$-) and some perfects (cf. vrj 'turn; prepare, lay'- vavrje 'has been laid'). In aorists this phenomenon is determined by the quantity of the root syllable: the reduplication vowel remains short before a long root syllable and becomes long before a short root syllable. By contrast, in perfects it is largely unpredictable, being caused by a phonetic law operating in the prehistoric period (lengthening before the root-initial laryngeal) and subsequent analogical developments; see Section 4.3 .2 below.

\subsection{Other morphological devices}

Other morphological devices used in the reduplicated formations include a connecting vowel between the reduplication syllable and the root in some intensives, accompanying suffixes (-sa- in desideratives, $-y a ́$ - in intensives), the thematic vowel $a$ before the endings (accordingly, the formations can be thematic or athematic) and the type of inflexion. For reasons of space, I will not discuss in detail the relevant morphological techniques (morphemes), but only mention some of them in the table below. 


\section{Reduplication paradigm}

The morphological techniques described above are summarized in Table 1, which represents a kind of 'reduplication paradigm' and shows how the reduplication vowel depends on the root vowel:

Table 1. Reduplication paradigm

( $R$ stands for $l, m, n$ )

\begin{tabular}{|c|c|c|c|c|c|}
\hline & \multicolumn{4}{|c|}{ root vowel } & \multirow{2}{*}{$\begin{array}{c}\text { other morphological } \\
\text { devices }\end{array}$} \\
\hline & $\breve{a}$ & $r$ & $\ddot{I}$ & $\check{u}$ & \\
\hline$i$-present & $i$ & \multirow{2}{*}{$i(a)$} & \multirow{2}{*}{$i$} & \multirow{2}{*}{$u$} & only thematic \\
\hline$a$-present & $a$ & & & & thematic/athematic \\
\hline perfect & \multicolumn{2}{|c|}{$\ddot{a}$} & $\dddot{t}$ & \multirow{2}{*}{$\check{u}$} & perfect endings \\
\hline aorist & & $\underline{I}$ & & & thematic/athematic \\
\hline desiderative & \multicolumn{3}{|c|}{$i(i)$} & $u$ & suffix $-s a-$ \\
\hline intensive & $\bar{a}, a R$ & $a r$ & $e$ & $o$ & $\begin{array}{l}\text { I: }- \\
\text { II: suffix }-y a ́-\end{array}$ \\
\hline
\end{tabular}

There are also a few hybrid formations, such as the perfect with intensive reduplication, or 'intensive perfect'" (cf. nu 'roar' - nonāva 'roars (repeatedly)'; see Schaefer 1994: 45; Kümmel 2000: 283), and perfect with present endings / present derived from perfect stems (cf. jar 'become awake' $j a ̄ g a ́ r-t i$ 'watches', $d \bar{l}$ 'shine' - 3pl.act. $d \bar{l} d y$-ati '(they) shine'; see Kümmel 2000: 191-194, 227-230).

For the sake of convenience, I have made a distinction between two present types, differing in the reduplication vowel for $a$-roots $(i$ or $a$ ). These two subtypes do not of course form two different 'present tenses'. The choice of the reduplication vowel cannot be predicted by the shape of the root; for a diachronic explanation of this split of one single present formation see Section 4.3.1 below.

This paradigm represents a maximum set of reduplication types, which a root can theoretically form; in most cases only some of these types can be derived from a given root. The paradigm is illustrated in Table 2 by the reduplication formations made from a few sample roots (I quote 3sg.act. forms if attested, otherwise bare stems; late (i.e. post-Vedic) formations are given in square brackets): 
Table 2. Reduplication paradigm for sample roots

\begin{tabular}{|c|c|c|c|c|c|}
\hline & han $^{8}$ 'hit' & $h \bar{a}$ 'leave/go', & $b h \bar{l}$ 'fear' & $y u$ 'separate' & $t \bar{r}$ 'cross' \\
\hline$i$-pres. & jighn- & jîhi- 'go' & \multirow{2}{*}{ bibhi- } & \multirow[b]{2}{*}{$y u y o-t i$} & \multirow{2}{*}{ titr- RV } \\
\hline$a$-pres. & - & jáhä-ti 'leave' & & & \\
\hline perfect & jaghána & jahau & bibhāya & $y u y \bar{\alpha} v a \mathrm{JB}$ & $\overline{t a t \bar{a} r-a}$ \\
\hline aorist & [ajīghanat] & - & $\begin{array}{l}\text { bïb- } \\
\text { haya- }\end{array}$ & $y \bar{u} y o-$ & átītara- $\mathrm{AV}$ \\
\hline desid. & jíghāmsati & jíhäsa-ŚSB & - & yúyūṣa- RV & titīișa- \\
\hline \multirow[t]{2}{*}{ intens. } & $\begin{array}{l}\text { janighanti, } \\
\text { ghánighn- }\end{array}$ & - & - & yóyuv- & $\begin{array}{l}\text { tartarìti, } \\
\text { táritr- }\end{array}$ \\
\hline & [janghanya-] & & & - & - \\
\hline
\end{tabular}

Tables 1-2 clearly show how often different types share the same reduplication syllable (see already Delbrick 1874: 101). Thus, the reduplication vowels for $i$ - and $u$-roots are $\breve{l}$ and $\breve{u}$ in all reduplicated formations except intensives; the reduplication syllable for $a$-roots has $\breve{l}$ in the $i$-present and reduplicated aorist. Of course, in most such cases, the grammatical characteristics of the corresponding formations can be identified by other morphological devices, such as suffixes (cf. desiderative -sa-) or inflexion type (for instance, perfect endings normally can only be taken by perfect stems). Yet there are some overlaps between paradigms where grammatically ambiguous forms can be found.

For instance, the active injunctives $2 \mathrm{sg}$. tütos (RV 6.26.4) and 3sg. tütot (RV 2.20.5, 2.20.7), both made from the root $t \bar{u}$ 'be strong', can belong either to the perfect or to the reduplicated aorist (see Macdonell 1910: 375, fn. 2; Lubotsky 1997a: 1, 600; Kümmel 2000: 220-221). Forms built on the reduplicated stem $d a d h$ - (root $d h \bar{a}$ 'put') may be either perfects or presents (cf. middle participle dádhāna- 'putting' or 'having put'), unless the inflexion unambiguously identifies the type of formation. The non-indicative forms made from the stem yuyo- ( $y u$ 'separate, keep away') may belong either to the reduplicated present or to the perfect; see Bendahman 1993: 164-165; Kümmel 2000: 401-405.

The overlaps between the reduplication types explain why they often influence (and borrow from) each other. A full list of such ambiguous forms would be extremely useful both for better understanding the origins of Vedic verbal morphology and for an adequate philological analysis of several text passages. 


\section{Reduplication in a diachronic perspective}

\subsection{General remarks}

Thus far I have only been concerned with a purely synchronic formal scheme. In what follows, I will briefly summarize the main ideas, hypotheses and problems relating to the origin and history of these synchronic types. Some of these ideas have been adopted by scholars and have been common knowledge already since the beginning of Indo-European and Vedic studies; others are still the subject of debate.

It is of course impossible to discuss (or even mention) all problems related to the origin of individual reduplicated types in a short survey. Thus, I will not enter into a discussion of the original accent placement and accent shifts in various reduplicated formations. Nor will I investigate the (largely neglected) issue of the rise and spread of vowel harmony in the reduplication syllable of the formations built on $i$ - and $u$-roots (which I call 'harmonizing roots' here). ${ }^{11}$ I will also abstain from discussing numerous suggestions on possible borrowings of reduplication types (vowels) from one formation by another (such as those mentioned in Section 4.3.1 below), most of which are very difficult to prove or to falsify.

Several details of the reconstruction can only be obtained on the basis of a comparison with other Indo-European branches, which I will skip for reasons of space; thus, I will not discuss at length evidence from Greek, Latin, Hittite, Slavic, and other Indo-European languages, only briefly mentioning them in a few cases; for details and bibliography, see, for instance, Szemerényi 1970: 248-250, 266-276 $\approx$ 1996: 268-270, 285-294; Sihler 1995: 487-490, 495-496, 507-508, 525, 573, 579-580.

\subsection{Reconstructed reduplication types}

The original reduplication types can be tentatively reconstructed as shown in Table $3\left(C_{R}=\right.$ reduplication consonant, $C_{1}=$ first root consonant, $C_{2}=$ the root consonant which follows the root vowel ${ }^{*} e$ ): 
Table 3. Inherited reduplication types and innovations

Indo-European inheritance

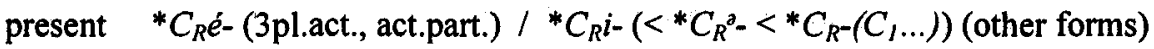

perfect ${ }^{*} C_{R} e-$

intensive $\quad{ }^{*} C_{R} e C_{2^{-}}$

desiderative $\quad{ }^{*} C_{R} i-\left({ }^{*} C_{R} u\right.$ - for $u$-roots $)$

\section{Indo-Aryan innovation}

aorist

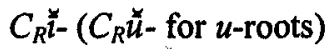

4.3. Indo-European inheritance and innovations

4.3.1. a-vs. i-presents ${ }^{12}$

The problem of the original reduplication vowel ( $a$ or $i$ ) in the class III presents derived from $\ddot{a}$-roots has puzzled many Indo-Europeanists (see e.g. Delbrück 1874: 104-105; Meillet 1903: 215; Adrados 1963: 683-684; Tischler 1976: 16, with fn. 41-42; Sihler 1995: 487). On the basis of the evidence from Greek, where $i(l)$ appears almost without exception, some scholars suggested that, as in Greek, all presents had $i$, and $a$ was secondarily introduced, supposedly from the perfect stems (M. Leumann 1952: 27; Emeneau 1958: 410). The reason for such an innovation remains unclear, however. By contrast, Hirt (1928: 9) suggested that in many cases $i$ was secondarily introduced under the influence of $i$ roots - again, without offering any explanation. ${ }^{13}$

In my view, most attractive is Kortlandt's (1987: 222; 1999) solution of the problem (see also Rasmussen 1984: $124 \approx 1987$ : 112; 1988: 125; 1997 : 252-253). According to Kortlandt, the reduplication vowels $a$ and $i$ go back to the full and zero grade of the reduplication syllable, which are reconstructed for Proto-Indo-European as ${ }^{*} C_{R} e$ - (thus the same as in the perfect) and $C_{R^{-}}$, respectively. The full grade appeared in the $3 \mathrm{pl}$. active form and active participles, the zero grade in the rest of the paradigm, for instance:

*dheH- 'put': 3pl.act. *dhé-dhH-nti - 3sg.act. *dh-dhéH-ti

Apparently, zero yielded a difficult sequence of consonants $\left({ }^{*} C_{R^{-}} C_{l} \ldots\right)$, usually a geminate $\left({ }^{*} p p \ldots,{ }^{*} t t \ldots,{ }^{*} m m \ldots,{ }^{*} d d h \ldots\right.$, etc. $)$. A mere simplifica- 
tion into one single consonant ${ }^{*} C_{l} \ldots$ (which was not rare with such clusters) would deprive the reduplicated present of its morphological characterization; for that reason the cluster was resolved into ${ }^{*} C_{R} i C_{l} \ldots$, where $i$ may represent the phonetic reflex of *a, 'shwa secundum' (F. Kortlandt, A. Lubotsky, p.c.), ${ }^{14}$ a non-phonemic vocalic sound, which appears as the zero grade of the PIE ${ }^{*} e$ in certain phonological contexts and yields $i$ not only in Indo-Iranian (as a ['shwa primum'] did), but (probably) already in Proto-Indo-European. ${ }^{15}$ In our case, it yielded $i$ except in reduplication syllables for $u$-roots, where it was "colored" by the root vocalism (again, perhaps already in Proto-Indo-European; see Güntert 1916: 100-107).

Most reduplicated presents have generalized one or another grade of the reduplication syllable, i.e. $a$ or $i$ (see below). Thus, instead of the expected 3sg.act. **di-dhấ-ti (root dhā- 'put'), we find 3sg.act. dá-dhā-ti, with the reduplication vowel $a$, taken from 3 pl.act. dá-dh-ati.

Yet, the original distribution can still be seen in a few verbs, which thus represent conclusive evidence for Kortlandt's reconstruction (see Kortlandt 1999). One such instance is sac 'follow', which preserves the alternation of the reduplication vowel within the paradigm: 3 pl.act. sáśc-ati '(they) follow' 3sg.act. sisak-ti '(s/he) follows' (with secondary accent retraction, probably triggered by the influence of the 3 pl.act. form). Another piece of evidence is the verb $h \bar{a}_{l / 2}$, originally one single lexical unit (root), which has split into two verbs in Vedic: $h \bar{a}_{l}$ 'leave', with the present derived from the $a$-stem (3sg.act. jähä-ti '(s/he) leaves', 3pl.act. jah-ati '(they) leave' etc.), and $h \bar{a}_{2}$ 'go (forth)', with the present derived from the $i$-stem (3sg.med. jihi-te '(s/he) goes (forth)'). The present jigäti (gā 'go') has the reduplication vowel $i$ throughout the paradigm, but $a$ is preserved in the fossilized participle jágat- '(living) world' (lit. 'going; [everything] that moves'); see Thieme 1929: 54; Narten 1972.

There are two more reduplicated presents which preserve traces of both grades, but the original distribution of the forms has been blurred. The verb $r \bar{a}_{l}$ 'give' has generalized $a$ in the reduplicated present, which is attested almost exclusively in the middle diathesis (2sg.inj. rarithāh, 3 sg.subj. rárate, 2 pl.impv. rarīhvam, part. ráräṇa-), except for one isolated active form, 2 sg.impv. ririh $i$, which may have preserved a different grade due to the fixed character of the sacral formulae where this form occurs ('give us [wealth, rain, cattle, etc.]'). The reduplicated present of vas' 'desire' is attested only twice: 2 sg.act. vavákși (RV 8.45.6), 3sg.act. vivaști (RV 7.16.11) (see Joachim 1978: 151). ${ }^{16}$ 


\subsubsection{Reduplication vowel of the perfect}

The original quality of the reduplication vowel of the perfect (PIE *e > Indo-Iranian $a$ ) is richly supported by the evidence from many IndoEuropean branches, as well as by the palatalization of the gutturals (velars) in Indo-Iranian $\left(\mathrm{ca}-<{ }^{*} \mathrm{ce}=<{ }^{*} k e-\right.$ etc. $)$.

The secondary length has expanded from a few forms where it results from the regular phonetic development of the vowel before a laryngeal, such as $m r j$ 'wipe, cleanse' - 3sg.med. mämrjé 'is wiped, is cleansed' < *Hme-Hmrǵ-, vrj 'turn; prepare, lay' - 3sg.med. vavrje 'has been laid' < *Hue-Hurg-, vrdh 'grow, increase': 3pl.act. vavrdhúr 'they have grown, increased' < *Hue-Huldh- (see Krisch 1996: 24-29; Jamison 1999).

Already in the prehistoric period, the long reduplication was extended to some roots without an initial laryngeal, due to several heterogeneous factors. First of all, there is a general tendency to generalize the long vowel before a short root syllable, whereas before a long root syllable, i.e. in 'strong' forms (= most of the singular active forms of the paradigm ${ }^{17}$ ), the short vowel is preferred, cf. vrdh 'grow': 3pl.act. vavrdhü - 3sg.act. vavárdha (see Renou 1924; Kümmel 2000: 21-22, 469-473 et passim). As in the case of reduplicated aorists (see below), the reason may be of a phonetic and/or prosodic nature, representing the tendency to alternate between long and short vowels in metrical texts. Furthermore, the long reduplication seems to be preferred by roots of certain structures, particularly, in the perfects of $C a r C$ and $v a(R) C$ roots, such as $k l p$ 'fit, arrange' - $c \bar{a}-k l p$-, vañ 'move (waveringly)' - vā-vak-, van 'like' - vā-van- (see Kümmel 2000: 21-22). Finally, there was a tendency to use the long reduplication vowel for perfects which are mostly or exclusively employed with present resultative (stative) meaning, such as jar 'become awake' - jāgára 'is awake' ( 'has awoken'), dī 'shine' - dìdấya 'shines'; see Delbrück 1888: 297; Kümmel 2000: 21-22, with fn. 10, 191-194, 227-230 et passim. Moreover, there are even a few perfects sporadically using the long reduplication in order to emphasize the present (stative) meaning as opposed to the preterital (PRET.) usages of the perfect of the same root, cf. tan 'stretch': tatāna 'has stretched (PRET.), stretches (PRES.)' (cf. (1)) tätāna 'stretches (PRES.)' (cf. (2)), vrt 'turn': vavarta 'has turned (PRET.), turns (PRES.)' $\sim$ vävarta 'turns (PRES.)' (Kümmel 2000: 21-22, 208-211, 462-469): ${ }^{18}$ 
(1) RV 10.178.3)

yáh sávasā pánca krștíh ...
who:NOM force:INS five .âna ...
'... who has stretched with his force across five peoples.'

(2) (RV 1.105.12)

$\begin{array}{ll}\text { satyám tatāna } & \text { súryah } \\ \text { truthfully stretch:PF(-PRES).3SG.ACT } & \text { sun:NOM } \\ \text { 'The sun truthfully stretches.' } & \end{array}$

\subsubsection{Reduplicated aorist}

The reduplicated (causative) aorist is an Indo-Aryan innovation, created as a formation corresponding to the present causatives with the suffix -áya-. Historically, it probably goes back to the imperfect of the reduplicated present, and the source of this formation could be just one single (but very frequent) reduplicated present, *(a)jijanat 'generated' (or athematic *(a)jijan, with secondary thematicization), made from the root jan 'be born; generate', as M. Leumann (1962) has argued; see also Bendahman 1993: 121-126; Harđarson 1997: 96-99; Rasmussen 1997: 257. All non-harmonizing roots show the reduplication vowel $\vec{l}$, with the exception of two non-causative aorists, ápaptat 'flew' (root pat 'fly', for which also the regular causative aorist with the $i$-reduplication is attested, ápipatat 'made fly') and ávocat (<*He-ue-unk"-et, where the diphthong *eu yields $o$ ) 'said' (root vac < * uek" - 'say'); for a few other possible members of this non-causative group, see Bendahman 1993: 194-205. Probably, $i$ has been generalized because 3pl.pres.act. (*jajanati '(they) generate' etc.) belongs to the lost part of the paradigm (present tense properly speaking). Once the reduplicated aorist was associated with causatives, the vocalic timbre $i$ could be reinterpreted as a marker of the causative meaning, in order to differentiate this formation from the imperfects of the reduplicated presents. This may also explain why the non-causative aorists ápaptat and ávocat have generalized $a$ instead of $i$.

As for the lengthening of the reduplication vowel, it could be analogically triggered by the lengthened grade root in the causative present, cf. pat 'fly': present causative patáyati 'makes fly' - aorist causative -pipatat, so that the stems of both formations follow the same metrical scheme: "long syllable + short syllable" (Jamison 1983: 217-218), probably supported by the tendency to alternate long and short vowels in metrical texts (for a general discussion, see Bendahman 1993: 119-120). 


\subsubsection{Intensive}

The intensive can be traced back as far as Proto-Indo-European (see Schaefer 1994: 48-71). The reduplication syllable shows full grade ('guna') for sonant roots (i.e. $e, o, a R<$ Indo-Iranian * $a i$, * $a u$, * $a R$ in the intensive stems made from the roots of the structure $\mathrm{Ci}(\mathrm{C}), \mathrm{Cu}(\mathrm{C}), \mathrm{CaR}(\mathrm{C})$, respectively) and lengthened grade for $C a C$ roots: $t i j$ 'be sharp' - té-tij-, $n u$ 'roar' - no-nu-, $d h r$ 'hold' - dár-dhr-, nad 'sound' - ná-nad-; for details, see Schaefer 1994: 22-35, 52-71; Lubotsky 1997b: 559-561.

\subsubsection{Desiderative}

The Indo-European origin of the Indo-Iranian desiderative is confirmed by the parallel formation in Celtic (Old Irish), even in spite of the lack of similar formations in other branches (see, for instance, Emeneau 1958: 410415; Szemerényi 1970: 266-269 ₹ 1996: 285-288; Sihler 1995: 507-508; Rasmussen 1987: 113; 1997: 254-256). The reduplication vowel is $i$ for non-harmonizing $(V \neq \breve{u}, \breve{l})$ roots, except for a few roots which have long reduplication (yabh 'copulate' - yi-yapsa-, $t \bar{r}$ 'cross' - tú-türşa-), partly reflecting the initial laryngeal, partly due to some analogical developments; for details, see Emeneau 1958: 414; Heenen 2002: 43-44.

Alongside the large class of desideratives with the regular $i / u$-reduplication, there is a small group of desiderative stems of the type (C) $\mathrm{i}_{\mathrm{Cs}} \mathrm{C}$-, made from $(C) a ̆ a C$ roots (sometimes with an idiomatic semantic shift), cf. $\bar{a} p$ 'obtain' - ípsa-, dabh 'deceive' - dipsa-, bhaj 'share' - bhikșa- 'beg', etc. Historically, these stems go back to reduplicated formations (dipsa- < * $d i$-dbh-sa-etc.), but synchronically they are not considered reduplicated any longer; see Heenen 2002: 35-38.

\section{Semantics and iconicity of the reduplicated formations}

The semantics of verbal reduplication is particularly intriguing, as it is probably the only morphological device which can be treated as iconically motivated by the meaning. No wonder it has been subject of numerous speculations from the very beginning of Indo-European comparative grammar. However, the only verbal formation where the iconic character of the reduplication is unquestionable is the intensive (note also the type of the intensive reduplication, which copies the root in the most complete and 
transparent fashion). Both the intensive and frequentative meanings (which are ascribed to this formation in Vedic) ${ }^{19}$ can be readily associated with the repetition (redoubling) of the root.

Much more questionable is the iconicity of the other reduplicated formations.

\subsection{Present}

The aspectual meaning of the reduplicated present has caused heated debate among Indo-Europeanists (for a survey, see Giannakis 1997: 11-20). Neogrammarians and their followers (Delbrück, Brugmann, Debrunner, M. Leumann) usually ascribed intensive, iterative, durative and similar meanings (actionalities, or Aktionsarten) to this formation. By contrast, another group of scholars, among whom French linguists prevailed (Vendryes, Meillet, Brunel, Specht), saw perfective, terminative or punctual meaning(s) here - which, in a sense, is nearly the opposite of the former. Holt (1943) determined the meaning in question as "aspect évolutif", i.e. basically durative with no terminus of the process - which approximately corresponds to what might be called 'atelic' in modern terminology (see, for instance, Dahl 1981). ${ }^{20}$

All these statements are extremely difficult to prove or refute. Although they all hold true at least for some part of the reduplicated presents, numerous counter-examples can easily be found, and thus neither of the hypotheses is supported by the bulk of the material.

Here I would like to draw attention to quite a different solution to the problem, which seems most attractive to me. It has appeared in an article by Ul'janov (1903), published about 100 years ago in Russian - and probably for that reason largely forgotten or neglected (one of the few exceptions is the Vedic grammar by Elizarenkova (1982); see also Elizarenkova 1961). The author claims that the common semantic denominator shared by many verbs which form reduplicated presents is the divisibility of the corresponding situation into (elementary) micro-situations. To use a physical metaphor, all these situations are quantized; in other words, the corresponding activities can be represented as series (chains) of elementary microactivities: drinking (Ved. pibati) as a series of sips, smelling (Ved. jighrati) as a series of sniffs, going (Ved. jigāti) as a series of steps. ${ }^{21}$ The same holds for many other verbs which form reduplicated presents, such as drive (cattle) (Ved. îjate < PIE *Hi-Hǵ-e-), chew (Ved. bábhasti), laugh (Ved. part. jákșat-), bellow (Ved. mímāti), sharpen (Ved. siśśäti). 
There remain a few reduplicated presents whose meanings cannot be taken as divisible, in particular, a few undoubtedly old formations, clearly inherited from Proto-Indo-European, cf. $d h \bar{a}$ 'put' - dádhāti, dā 'give' - dádāti. Nevertheless, Ul'janov's explanation seems to offer the best coverage of the bulk of the Indo-European reduplicated presents and prompts a possible scenario for the development of this morphological type. Perhaps, the expansion of reduplicated presents has begun from a few frequent verbs denoting divisible situations (such as, for instance, pibati or jigäti), with the subsequent attraction of verbs with similar semantics. (Note that the divisibility is an inherent feature of the verb (predicate), which does not make different aspectual usages impossible: iterative, durative, terminative, etc.) Later on, some other meanings could be (secondarily) associated with these presents, so that, from the semantic point of view, this formation has become less homogeneous. ${ }^{22}$ In particular, the above-mentioned atelic analysis (in other terms, "ziellose Aktivität", "aspect évolutif") and/or iterative interpretation seem very likely for a number of reduplicated presents, especially for those opposed to non-reduplicated presents. In such cases the latter formation usually either shows a telic (non-iterative etc.) meaning or is simply non-specified as far as this semantic opposition is concerned. Two particularly instructive examples are the verbs bhr 'carry, bring' and nas 'approach, reach, return (home)'.

In the case of bhr, the thematic full grade root present (class I in the traditional notation) with a telic (or non-specified) meaning, bhárati 'brings' (cf. Germ. bringen, Rus. (pri)nesti), is opposed to the reduplicated present bibharti 'carries' (cf. Germ. tragen, Rus. nosit'), employed with an atelic (or iterative) meaning; see Delbrück 1897: 18 ("bibharti ... wird von der nicht auf ein Ziel gerichteten Thătigkeit des Tragens gebraucht"); Joachim 1978: 116-117; Gotō 1987: 225-227. Cf. an especially clear instance of the opposition 'telic/atelic' in (3):

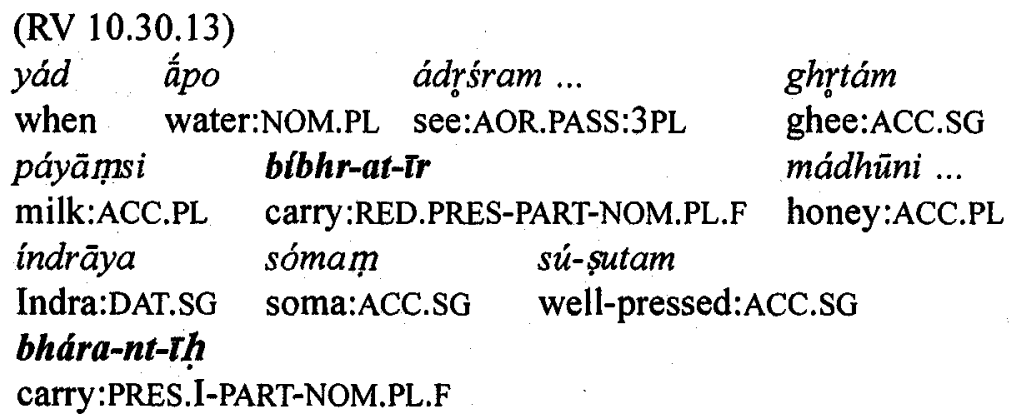


'When the waters, which carry [bibhratīr] ghee, milk and honey, which bring [bhárantīh] the well-pressed soma-sap to Indra, became visible ...'

The class I present of nas, násate, is employed with the telic meaning ('approach, reach, return (home)'), whilst the reduplicated present nims(3pl.med. nimsate, part.med. nimsäna-) renders repeated movements ('touch (in)'); see Gotō 1987: 200-201. The repetitive or iterative character of the activity expressed by the reduplicated present is particularly clear from the contexts where it describes the motion of the sacrificial spoons pouring oblation into the flame, as in (4), or the licking movements of a flame, which touches the spoons, as in (5):

(4) (RV 1.144.1)

$\begin{array}{llll}\text { srucah ... } & y a ́ & \text { asya } & \text { dhắma ... } \\ \text { sacrificial.spoon:NOM.PL } & \text { which:NOM.PL.F } & \text { his } & \text { abode:ACC.SG } \\ \text { nims-ate } & & & \end{array}$

reach:RED.PRES-3PL.MED

'... the sacrificial spoons ... which touch his (fire's) abode ...'

(5) (RV 8.43.10)

$\begin{array}{lll}\operatorname{arct}_{\hat{l}} & \text { rocate ... } & \text { nims-anam } \\ \text { flame:NOM.SG } & \text { shines } & \text { reach:RED.PRES-PART.MED:NOM.SG.N } \\ \text { juhvò } & \text { múkhe } & \end{array}$

spoon:ACC.PL mouth:LOC.SG

'The flame shines, ... touching the spoons at their mouths $[=$ front part]'.

A few other examples of a similar semantic opposition between the nonreduplicated and reduplicated presents are:

- pad 'fall, move': the -ya-present pádyate 'falls, moves' (unspecified motion) is opposed to the reduplicated present pibda- 'trudge, plod' (atelic; in Strunk/Gotō's description, 'stapfen, auf der Stelle treten'), attested in the middle participle pibdamāna- (see Strunk 1977: 977-980; Gotō 1987: 280, fn. 650);

- $t \bar{r}$ 'cross (over)': class I present tárati 'crosses (over)' (telic) is opposed to the iterative reduplicated present titr- 'step, make step' (attested in the participle titrat- RV 2.31.2); see Gotō 1987: 160-161 and 165;

- $a j$ 'drive (of cattle etc.)': class I present ájati 'drives' is opposed to the reduplicated present íjate (< PIE * Hi-Hǵ-e-). ${ }^{23}$ 
It remains unclear what could be the ground for the distribution of the two reduplication types $(a$ or $i$ ) in the presents derived from $a$-roots. The choice of the vowel may appear to be purely accidental. Yet a comparison of the lists of the $a$ - and $i$-presents reveals a few features shared by most or many of the members of the latter group as opposed to the former, cf. Table 4 (forms in the columns to the right of the roots are 3 rd person singular active, unless specified otherwise):

Table 4. $a$ - and $i$-presents

\begin{tabular}{|c|c|c|c|}
\hline \multicolumn{2}{|c|}{$a$-presents } & \multicolumn{2}{|c|}{$i$-presents } \\
\hline \multicolumn{4}{|c|}{ athematic presents } \\
\hline & \multicolumn{3}{|c|}{ 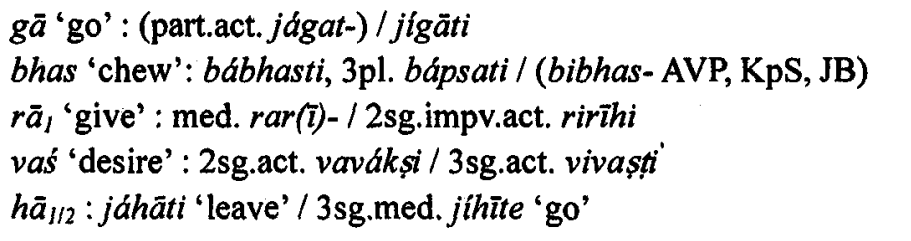 } \\
\hline $\begin{array}{l}\text { dā 'give': } \\
\text { dhã 'put': } \\
\text { yas 'boil': } \\
\text { sas 'sleep': } \\
\text { has 'laugh': }\end{array}$ & $\begin{array}{l}\text { dádāti } \\
\text { dádhāti } \\
\text { 3sg.impv. yayastu } \\
\text { (RV 7.104.2) } \\
\text { sásasti, sasásti (YV) } \\
\text { part.act. jákşat- }\end{array}$ & $\begin{array}{l}\text { nas 'approach': } \\
p \bar{a}_{2} \text { 'move': } \\
m \bar{a}_{1} \text { 'measure': } \\
m \bar{a}_{2} \text { 'bellow': } \\
v a c \text { 'speak': } \\
s \bar{a} \text { 'sharpen': }\end{array}$ & $\begin{array}{l}\text { 3pl.med. nimsate } \\
\text { 3sg.med. pipīte } \\
\text { mímāti } \\
\text { mímāti } \\
\text { vivakti } \\
\text { sísáti }\end{array}$ \\
\hline \multicolumn{4}{|c|}{ thematic presents } \\
\hline & & $\begin{array}{l}\text { aj 'drive': } \\
\text { ghrä 'smell': } \\
\text { pad 'move': } \\
\text { pā 'drink': } \\
\text { sad 'sit (down)': } \\
\text { sthä 'stand': } \\
\text { han 'hit': }\end{array}$ & $\begin{array}{l}\text { 3sg.med. îjate } \\
\quad(<* H i-H g ́-e-) \\
\text { jíghrati } \\
\text { part.med. píbdamāna- } \\
\text { píbati } \\
\text { sídati }(<* \text { sí-sd-e-) } \\
\text { tíșthati } \\
\text { 3sg.med. jíghnate }\end{array}$ \\
\hline
\end{tabular}

(i) The majority of the $i$-presents are built to $\bar{a}$-roots, going back to Proto-Indo-European roots in a laryngeal ( $g \bar{a}$ ' $\mathrm{go}^{\prime}<{ }^{*} \mathrm{~g}^{\prime \prime} e \mathrm{H}_{2-}, \mathrm{p} \bar{a}$ ' $\mathrm{drink}$ ' $<$ ${ }^{*} \mathrm{peH}_{3-}$, etc.). By contrast, although there are a few $\bar{a}$-roots in the $a$-class, 
the structure Cas seems to prevail. I suppose that the reduplication vowel $i$ may have been reanalyzed as the weak grade of the laryngeal vocalized in interconsonantal position (i.e. $i<{ }^{*} H_{0}$ ) and, accordingly, as a vowel copying the weak grade of the root - in analogy with the presents built on $i$ - and $u$-roots, i.e.:

$$
\begin{aligned}
& m \tilde{a}\left({ }^{*} m a H-\right) / m i\left({ }^{*} m H_{0}-\right): m i-(m a ̄ t i)=v e s\left({ }^{*} \text { uajs-) } / \text { viș }:\right. \text { vi-(vești) } \\
& =y \boldsymbol{o}\left({ }^{*} j a u-\right) / y \boldsymbol{u}: y \boldsymbol{u}-(y o t i)
\end{aligned}
$$

(ii) The fact that four of the five roots in $-s$ (structure Cas) which form class III presents reduplicate with $a$ may be not accidental. The $i$-reduplication of a Cas root yields the stem $C_{R} i C^{\prime} s$ - (where $C^{\prime}$ stands for the voiceless and non-aspirated pendant of $C$ ) in the forms with the zero grade of the root, e.g. in 1 pl.act. (bhas - **bips-mas(i) etc.). The thematic variant of such a stem would be identical to the stem of the desiderative of the type CiCsa-, made from (C) $\breve{a} C$ roots (e.g. dabh 'deceive' - dipsa-; see Section 4.3.5). The tendency to avoid the possible (quasi-)homonymy with desideratives might be one of the reasons for generalizing the $a$-reduplication.

(iii) All reduplicated presents which have generalized the thematic stem throughout the paradigm are found in the -i-class (see e.g. Rasmussen 1988: 112-113; Niepokuj 1997: 192). Most likely, the presence of the thematic vowel $(\mathrm{PIE} * e)$ prevented the appearance of yet another full grade $\left({ }^{*} e\right)$ in the stem, according to the rules of Proto-Indo-European morphophonemics (A. Lubotsky, p.c.).

(iv) The fact that all media tantum presents belong to the -i-class is easily accounted for in terms of Kortlandt's hypothesis, since all middle forms show the zero grade of the reduplication syllable.

(v) Finally, about half of the presents with the $i$-reduplication (including those made from $i$ - and $r$-roots) belong to verbs of motion (íjate (<*Hi-Hǵ-e-) 'drives', iyarti 'comes, rises' [root r]], jígāti 'goes, steps', títr- '(make) step', nims- 'touch (in)', pibda- 'trudge, plod', piparti 'makes cross over' [root pr], bibharti 'carries', etc.), which are (nearly) lacking in the $a$-class. At some stage the $i$-reduplication could have been considered as a feature of this semantic subgroup, as opposed to the verbs, with a different semantics. Such a development could be triggered by just a few $i$-presents, but, again, the exact reasons for this process remain unclear. Perhaps the choice of the reduplication vowel was influenced by the perfect, according to the following scenario. The vowel in the full grade of the reduplication syllable of the present is the same as in the perfect $(a<* e)$. Verbs of motion can easily be 
used in atelic/iterative usages, which, in a sense, represent nearly the opposite of the perfect-resultative meaning. For that reason, the presents of such verbs may tend to formal differentiation from the perfect reduplication and, accordingly, to the generalization of the reduplication vowel $i$.

\subsection{Perfect}

More problematic is the iconic character of the reduplication in the perfect. Theoretically, it is not impossible to figure out some aspects of the perfect meaning that could motivate this morphological process. For instance, the canonical meaning of the Indo-European perfect, an activity in the past, which results in a state in the present (e.g. ' $\mathrm{X}$ has grown' $\approx$ ' $\mathrm{X}$ was growing and now $\mathrm{X}$ is big/grown'), can be considered as consisting of two overlapping meanings ('performing $\mathbf{P}$ ' + 'result of P'). ${ }^{24}$ Whether this semantic fact could be considered as an instance of the reduplication of meaning and, accordingly, contribute to the development of the reduplication of form, remains of course pure guesswork.

\section{Concluding remarks}

As I mentioned before, the present survey does not claim to give an exhaustive description of the Vedic verbal reduplicated formations. Here I would like, above all, to draw attention to the fact that no general study of reduplication can disregard the Vedic evidence, since it furnishes valuable data for a general study of reduplication in a diachronic perspective, in particular for clarifying the role of iconicity in the rise of the reduplication and the role of analogical developments for its grammaticalization. Further research requires a detailed analysis of all Vedic reduplicated formations as members of one 'reduplication paradigm', in order to determine the main patterns of syncretisms and analogical developments. 


\section{Abbreviations}

$\begin{array}{llll}\text { ACC } & \text { accusative } & \text { LOC } & \text { locative } \\ \text { act. } & \text { active } & \text { med. } & \text { middle } \\ \text { aor. } & \text { aorist } & \mathrm{N} & \text { neuter } \\ \mathrm{AV} & \text { Atharvaveda } & \text { NOM } & \text { nominative } \\ C_{l} & \text { first root consonant } & \text { part. } & \text { participle } \\ C_{2} & \text { the root consonant which } & \text { pl. } & \text { plural } \\ & \text { follows the root vowel } & \text { PIE } & \text { Proto-Indo-European } \\ C_{R} & \text { reduplication consonant } & \text { pres. } & \text { present } \\ \text { DAT } & \text { dative } & \text { red. } & \text { reduplicated } \\ \text { du. } & \text { dual } & \text { RV } & \text { Rgveda } \\ \text { F } & \text { feminine } & \text { sg. } & \text { singular } \\ \text { impv. } & \text { imperative } & \text { subj. } & \text { subjunctive } \\ \text { inj. } & \text { injunctive } & \text { SB } & \text { Satapatha-Brāhmaṇa } \\ \text { JB } & \text { Jaiminiya-Brāhmaṇa } & \text { YV } & \text { Yajurveda } \\ \text { KpS } & \text { Kapișthala-Kațha-Samphitā } & & \end{array}$

\section{Notes}

1. I am much indebted to B. Comrie, A. Griffiths, F. Heenen, F. Kortlandt, A. Lubotsky, B. Nielsen and T. Oberlies, as well as an anonymous reviewer for their criticism and valuable comments on earlier drafts of the paper. I also would like to take this opportunity to express my thanks to the audience of the Reduplication Conference in Graz (November 2002), in particular to W. Abraham, B. Hurch, F. Rojanski and Chr. Zinko, for suggestions and critical remarks. I particularly thank A. Griffiths for providing me with information on the readings of the Orissa manuscripts of the Paippalada recension of Atharvaveda [AVP] for AVP 19.31.14. I also acknowledge the Netherlands Organization for Scientific Research (NWO) for financial support, grant 22070-003 for the PIONIER project "Case cross-linguistically".

2. For a monographic description of the Greek reduplicated presents, see Giannakis 1997; for reduplicated presents in other Indo-European languages, see also Giannakis 1992.

3. For a discussion of Indo-European reduplication in general, see Tischler 1976 and the recent monograph by Niepokuj (1997), which gives a sketchy overview of various Indo-European branches. Unfortunately, her discussion of the Vedic reduplicated formations (perfect, present, intensive) is very superficial and even reveals poor knowledge of the relevant literature; thus, several important works dealing with the Vedic verbal reduplication (such as Kortlandt 
1987, M. Leumann 1952, 1962, Rasmussen 1987, 1988) are lacking in the bibliography. The book abounds in mistakes, misinterpretations, unconvincing explanations and ad hoc hypotheses, and most of the author's conclusions can hardly be taken seriously.

4. Deaspiration and palatalization fail to occur only in one subtype of intensives, which insert the connecting vowel $\vec{l}$ between the reduplication syllable and the root (cf. krand 'roar' - kan-i-krad-, bhr 'carry' - bhar-i-bhr-); see Schaefer 1994: 34-35, 55-71.

5. By 'the root vocalism' I mean (i) 'pure' vowels $a$ and $\bar{a}$ and (ii) vowel $a$ followed by a sonant or vocalic allophones of sonants: i/e (< Indo-Iranian * $\left.a_{l}\right)$, u/o (< Indo-Iranian * au), r/ar, l/al, an, am.

6. By contrast, the vocalic $r$ is never copied in the reduplication syllable, always being represented by $i$ or $a$.

7. See Lubotsky 1997b: 559; Kümmel 2000: 19-20.

8. < PIE * $g^{w h}$ en-, whence the alternation $h / g h$ in the root.

9. For $h \bar{a}$ and its split into two synchronically distinct roots, see Section 4.3.1.

10. For this type of intensive, see note 4.

11. The locus of this process may be the reduplicated present, where the vocalic element ${ }^{\circ}$ ('shwa secundum'; see Section 4.3 .1 ) could easily be colored by the root vowel.

12. I have greatly benefited from discussing several aspects of the reduplicated presents with F. Kortlandt and A. Lubotsky. Of course all responsibility for possible mistakes and misinterpretations is mine.

13. Niepokuj, after a lengthy discussion (1997: 191-195), fails to explain the reduplication vowel in the present.

14. According to Kortlandt's (1987: 222) formulation, ${ }^{*} i(<* \partial)$ has arisen as a zero grade of ${ }^{*} e$ only pretonically before double consonants (i.e. in such forms as 1pl.act. *dhi-dhH-més), whereas in other forms the zero grade of * $e$ was mere zero. Of course from forms like lpl.act. $i$ could easily expand to other zero grade forms, such as 3 sg.act. $\left({ }^{*} d(h)\right.$-dhéH-ti $\left.\rightarrow{ }^{*} d(h) i-d h e ́ H-t i\right)$.

A very similar description of the ablaut in the reduplication syllable (in terms of the "accent-conditioned distribution of the reduplicatory vowels") has been suggested by Rasmussen (1984: $124 \approx 1987$ : 112; 1988: 125; 1997: 252253).

15. For shwa secundum, see, for instance, Guntert (1916: 19-31, 92-100 et passim); Vine (1999).

16. Yet another root which may be added to this list is bhas 'chew'. It typically reduplicates with $a$ (cf. $3 \mathrm{sg}$. bábhasti, 3pl. bápsati), but in a mantra found with minor variants in several post-Rgvedic texts (Atharvaveda in two recensions, Saunakīya [AVŚ] and Paippalāda [AVP], Kāṭhaka [KS], KapișțhalaKațha-Sam̧hitā [KpS], Jaiminīya-Brăhmaña [JB], Taittirĩya-Āraṇyaka) we also find an occurrence of the 3sg.act. form babhasti, attested in some texts (manuscripts) with the non-standard $i$-reduplication: 3sg.impv.act. bibhastu (AVP 19.31.14) 3sg.ind.act. bibhasti (KpS 48:13:304.9 = JB 2.223:3; edi- 
tors of the texts everywhere emend to ${ }^{+}$babhasti) $\sim$ babhasti (AVS 6.49.1 = KS 35.14:60.9); see Renou (1952: 263) on the variant attested in the Kapișțhala-Kațha-Saṃhitā.

17. For a detailed description of the distribution of 'strong' and 'weak' forms within the paradigm, see Kümmel (2000: 23-42).

18. In this latter case we are dealing, in fact, with the embryo of a separate tense category, which might be called 'perfecto-present' (glossed as PF(-PRES) in example (2)).

19. For the meaning of the Vedic intensive, see Schaefer (1994: 75-93) and Praust (2000: 56), with fn. 112-113 ("[das Intensivum bezeichnet] eine mehrmalige Wiederholung [einer Aktivităt], aufgefaßt als ein Vorgang").

20. Yet another "iconic" interpretation of the general meaning of the IndoEuropean reduplicated presents, which may be mentioned as a curiosum, has been suggested by $O$. Hoffmann (1899: 172-174). According to Hoffmann, a number of reduplicated presents denote activities typically performed by body parts which form natural pairs, cf. dádā- 'give', dádhā- 'put' (two hands), jigā- 'step', tiștha- 'stand' (two feet), and even piba- 'drink' (two lips!). Should we perhaps add the present sídati (<*si-sd-e-) 'sit (down)' (two buttocks!) to this list?

21. In fact, this definition more accurately renders the meaning of the verb: jigäti means stepping, treading, making steps rather than some non-specified motion (see, for instance, Delbrück 1897: 16-17; K. Hoffmann 1967: 274-275), cf::

(RV 10.73.3)

rssuá te pádā prá yáj jígā-si

high your foot:NOM.DU forward when tread:RED.PRES-2SG.ACT

'Your feet are high, when you (= Indra) are treading.'

22. Note, in particular, that we find in this class a few verbs which form natural semantic pairs and therefore could easily influence each other and induce each other's morphological features, cf. sad 'sit (down)': sídati (< *si-sd-e-) sthā 'stand': tișthati (see Meillet 1909: 265).

23. $a j$ and $i j$ became synchronically distinct roots already in the prehistoric period. Since most contexts allow of both iterative and non-iterative interpretations, the original alleged opposition (non-specified vs. iterative?) cannot be seen in the attested forms; see Strunk (1977); Joachim (1978: 36-37); Gotō (1987: 90).

24. Cf. Rasmussen (1997: 258): "[the] reduplicated stem-formation [of ${ }^{*} g^{w h} e-g^{w h} \delta n-h_{2} e$ 'I have killed'] may add a reference to [the] ... two-phase semantics which could perhaps be rendered as "I have killed and so now [the resulting situation prevails]" and (ibid., fn. 8): "[a]nother possible justification of the reduplication could be the use of the perfect to express an action that was started in the past and is being continued into the present." 


\section{References}

Adrados, Francisco Rodríguez

1963 Evolución y estructura del verbo indoeuropeo. Madrid: Instituto "Antonio de Nebrija".

Bendahman, Jadwiga

1993 Der reduplizierte Aorist in den indogermanischen Sprachen. (Deutsche Hochschulschriften 642) Egelsbach: Hänsel-Hohenhausen.

Dahl, Östen

1981 On the definition of the telic-atelic (bounded-nonbounded) distinction. In Syntax and Semantics 14. Tense and Aspect; Philip Tedeschi and Annie Zaenen (eds.), 79-90. New York: Academic Press.

Delbrück, Berthold

1874 Das altindische Verbum aus den Hymnen des Rgveda seinem Baue nach dargestellet. Halle a.S.: Verlag der Buchhandlung des Waisenhauses.

1888 Altindische Syntax. Halle a.S.: Verlag der Buchhandlung des Waisenhauses. (= B. Delbruck. Syntaktische Forschungen. V).

1897 Vergleichende Syntax der indogermanischen Sprachen. II. Theil. Strassburg: Trubner.

Elizarenkova, Tatjana Ja.

1961 Znacenie osnov prezensa $v$ "Rigvede" [The meaning of the present stems in the Rgveda]. In Jazyki Indii; M. Aslanov et al. (eds), 91165. Moskva: Izd-vo vostocnoj literatury.

1982 Grammatika vedijskogo jazyka [A grammar of Vedic]. Moskva: Nauka.

Emeneau, Murray B.

1958 Rev. of: M. Mayrhofer, Kurzgefasstes etymologisches Worterbuch des Altindischen. [Bd. II]. Fasc. 9-10. Heidelberg: Winter, 1957. Language 34 (3): 408-417.

Giannakis, Georgios K.

1992 Reduplication as a morphological marker in the Indo-European languages: reduplicated presents. Word 43 (1): 161-196.

1997 Studies in the syntax and the semantics of the reduplicated presents of Homeric Greek and Indo-European. (Innsbrucker Beiträge zur Sprachwissenschaft 90) Innsbruck: Institut fur Sprachwissenschaft der Universität Innsbruck.

Gotō, Toshifumi

1987 Die "I. Präsensklasse" im Vedischen: Untersuchung der vollstufigen thematischen Wurzelpräsentia. (Österreichische Akademie der Wissenschaften. Philosophisch-historische Klasse. Sitzungsberichte 489) Wien: Verlag der Österreichischen Akademie der Wissenschaften. 
Güntert, Hermann

1916 Indogermanische Ablautprobleme. Untersuchungen über Schwa secundum, einen zweiten indogermanischen Murmelvokal. (Untersuchungen zur indogermanischen Sprach- und Kulturwissenschaft 6) Strassburg: Trubner.

Harđarson, Jón Axel

1997 Bemerkungen zum reduplizierten Prăteritum II im Tocharischen und zum Kausativaorist im Altindischen. In Sound law and analogy. $\mathrm{Pa}$ pers in honor of Robert S.P. Beekes on the occasion of his 60th birthday; Alexander Lubotsky (ed.), 95-102. Amsterdam: Rodopi.

Heenen, François

2002 Le désidératif en védique. Ph. D. diss., Universităt Wien. Hirt, Hermann A.

1928 Indogermanische Grammatik. Tl. IV. Doppelung, Zusammensetzung, Verbum. Heidelberg: Winter.

Hoffmann, Karl

1967 Der Injunktiv im Veda. Eine synchronische Funktionsuntersuchung. Heidelberg: Winter.

Hoffmann, Otto

$$
\text { Heidelberg: Winter. }
$$

1899 Rev. of: K. Brugmann und B. Delbruck, Grundriss der vergleichenden Grammatik der indogermanischen Sprachen. Bd. IV: Vergleichende Syntax ... von B. Delbrick. TI. I-Il. Strassburg, 18931897. Beiträge zur Kunde der indogermanischen Sprachen (Bezzenbergers Beiträge) 25: 163-180.

Holt, Jens

1943 Études d'aspect. (Acta Jutlandica 15(2)) Kopenhagen: Munksgaard.

Insler, Stanley

1968 Sanskrit ípsati and trtsati. Indogermanische Forschungen 73: 57-66. Jamison, Stephanie W.

1983 Function and form in the -aya-formations of the Rig Veda and Atharva Veda. (Zeitschrift fur vergleichende Sprachforschung auf dem Gebiete der indogermanischen Sprachen. Ergănzungsheft 31) Göttingen: Vandenhoeck \& Ruprecht.

1999 Rev. of Krisch 1996. Kratylos 44: 59-62. Joachim, Ulirike

1978 Mehrfachprd̈sentien im Rgveda. (Europäische Hochschulschriften: Kortlandt, Frederik H.H. Reihe XXI, Linguistik 4) Frankfurt am Main: Lang.

1987 Archaic ablaut patterns in the Vedic verb. In Festschrift for Henry Hoenigswald: on the occasion of his seventieth birthday; George Cardona and Norman H. Zide (eds.), 219-223. Tubingen: Narr.

1999 Accent and ablaut in the Vedic verb. Paper presented at the 2nd International Vedic Workshop, Kyoto, 30 October - 2 November, 1999. [Available at: http://www.kortlandt.nl/publications/] 
Krisch, Thomas

1996 Zur Genese und Funktion der altindischen Perfekta mit langem Reduplikationsvokal. (Innsbrucker Beiträge zur Sprachwissenschaft 87) Innsbruck: Institut fur Sprachwissenschaft der Universităt Innsbruck.

Kümmel, Martin

2000 Das Perfekt im Indoiranischen. Eine Untersuchung der Form und Funktion einer ererbten Kategorie des Verbums und ihrer Entwick-

Leumann, Manu lung in den altindoiranischen Sprachen. Wiesbaden: Reichert.

1952 Morphologische Neurungen im altindischen Verbalsystem. (Mededelingen der Koninklijke Nederlandse Akademie van wetenschappen, Afd. Letterkunde 15/3). Amsterdam: Noord-Hollandsche Uitgevers Maatschappij.

1962 Der altindische kausative Aorist ajïjanat. In Indological studies in honor of W. Norman Brown; E. Bender (ed.), 152-159. New Haven: American Oriental Society.

Lubotsky, Alexander

1997a A Rgvedic word concordance. (American Oriental Series 82-83) New Haven: American Oriental Society.

1997b Remarks on the Vedic intensive. Journal of the American Oriental Society 117 (3): 558-564.

Macdonell, Arthur A.

1910 Vedic grammar. (Grundriss der Indo-Arischen Philologie und Altertumskunde I, 4) Strassburg: Trübner.

1916 A Vedic grammar for students. Oxford: Clarendon Press.

Meillet, Antoine

1903 Varia. Mémoires de la Société de linguistique de Paris 12: 213-238.

1909 Deux notes sur des formes à redoublement. In Philologie et linguistique. Mélanges offerts à Louis Havet ..., 263-278. Paris: Librairie Hachette.

Narten, Johanna

1972 jágat- im Rgveda. India maior: congratulatory volume presented to J. Gonda; Jacob Ensink and Hans Peter Gaeffke (eds.), 161-166. Leiden: Brill. [= J. Narten. Kleine Schriften, 190-195. Wiesbaden: Reichert]

Niepokuj, Mary Katherine

1997 The development of verbal reduplication in Indo-European. Journal of Indo-European studies, Monograph series 24. Washington, D.C.: Institute for the Study of Man.

Praust, Karl

2000 Studien zum indogermanischen Verbum. Ph. D. diss., Universităt Münster. 
Rasmussen, Jens Elmegård

1987 The make-up of Indo-European morphology. Diachronica 4: 107122. [Preprint in APILKU 4 (1984): 119-133]

1988 Indo-European ablaut -i- -e-/-o-. APILKU 7: 125-142.

1997 Processes of grammaticalization in Indo-European verbal morphology. In Sound law and analogy. Papers in honor of Robert S.P. Beekes on the occasion of his 60th birthday; Alexander Lubotsky (ed.), 249-262. Amsterdam: Rodopi.

Renou, Louis

1924 Védique vāurdhé, vāvrdhưh. Bulletin de la Société de Linguistique de Paris 24: 185-188.

1952 Grammaire de la langue védique. Lyon: IAC.

Schaefer, Christiane

1994 Das Intensivum im Vedischen. (Historische Sprachforschung. ErSihler, Andrew L. gănzungsheft 37) Göttingen: Vandenhoeck \& Ruprecht.

1995 New comparative grammar of Greek and Latin. Oxford: Oxford University Press.

Strunk, Klaus

1977 Zwei latente Fälle des verbalen Präsensstammtyps tíștha-(ti) im

Veda. In $X I X$. Deutscher Orientalistentag. Vorträge; Wolfgang Voigt (ed.), 971-983. (Zeitschrift der Deutschen Morgenländischen GeSzemerényi, Oswald J.L.

sellschaft, Supplement III, 2) Wiesbaden: Steiner.

1970 Einführung in die vergleichende Sprachwissenschaft. Darmstadt: Wissenschaftliche Buchgesellschaft.

1996 Introduction to Indo-European linguistics. Oxford: Clarendon Press. Thieme, Paul

1929 Das Plusquamperfektum im Veda. (Zeitschrift fur vergleichende Sprachforschung auf dem Gebiete der indogermanischen Sprachen. Tischler, Johann

Ergånzungsheft 7) Göttingen: Vandenhoeck \& Ruprecht.

1976 Zur Reduplikation im Indogermanischen. (Innsbrucker Beiträge zur Sprachwissenschaft. Vorträge 16) Innsbruck: Institut fur SprachwisUl'janov, Grigorij

senschaft der Universităt Innsbruck.

1903 Kratnoe znacenie udvoennyx osnov [The divisible meaning of the reduplicated stems]. Russkij filologičeskij věstnik 49: 235-249.

Vine, Brent

1999 Greek pí̧ $\alpha$ 'root' and 'schwa secundum'. In UCLA Indo-European Studies 1; Vjaceslav Ivanov and Brent Vine (eds.), 5-30. 


\section{Contents}

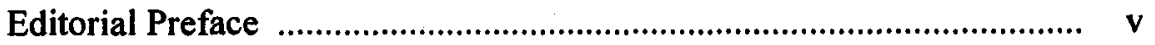

Introduction ...................................................................................

Bernhard Hurch

Reduplication: Form, function and distribution .................................. 11

Carl Rubino

From repetition to reduplication in Riau Indonesian ............................. 31

David Gil

Morphological Doubling Theory:

Evidence for morphological doubling in reduplication ......................... 65

Sharon Inkelas

The Emergence of the Marked: Tone in some African

reduplicative systems

Laura J. Downing

Reduplication and consonant mutation in the

Northern Atlantic languages

Fiona Mc Laughlin

Wrong side reduplication is epiphenomenal: Evidence from Yoruba

Nicole Nelson

Non-adjacency in reduplication

Patricia A. Shaw

Enhancing contrast in reduplication

Suzanne Urbanczyk

Phrasal reduplication and dual description

Elinor Keane

Reduplication in Modern Hindi and the theory of reduplication 263 Rajendra Singh 
On the grammaticalization of verbal reduplication in Japanese

Reijirou Shibasaki

Reduplicative allomorphy and language prehistory in Uto-Aztecan .... 315 Jason D. Haugen

Reduplication in Tupi-Guarani languages:

Going into opposite directions

Françoise Rose

On the borderline of reduplication:

Gemination and other consonant doubling in Arabic morphology

Dina El Zarka

Syntactic reduplication in Arabic

Utz Maas

Reduplication in the Vedic verb:

Indo-European inheritance, analogy and iconicity

Leonid Kulikov

Reduplication in child language

Wolfgang U. Dressler, Katarzyna Dziubalska-Kolaczyk,

Natalia Gagarina, Marianne Kilani-Schoch

Reduplication before age two

Marie Leroy and Aliyah Morgenstern

Acquisition of reduplication in Turkish

Hatice Sofu

Reduplication in Pidgins and Creoles

Peter Bakker and Mikael Parkvall

Less is more: Evidence from diminutive reduplication

in Caribbean Creole languages

Silvia Kouwenberg and Darlene LaCharité

Intensity and diminution triggered by reduplicating morphology:

Janus-faced iconicity

Werner Abraham

Backward and sideward reduplication in German Sign Language Roland Pfau and Markus Steinbach

A reanalysis of reduplication in American Sign Language

Ronnie B. Wilbur. 